\title{
MANFAAT DAN KEAMANAN MAKANAN FERMENTASI UNTUK KESEHATAN (TINJAUAN DARI ASPEK ILMU PANGAN)
}

\author{
Luh Masdarini \\ Jurusan PKK (Tata Boga), FTK, UNDIKSHA
}

\begin{abstract}
ABSTRAK
Makanan tradisional yang diproses melalui fermentasi, disebut dalam beberapa penelitian terbukti bahwa makanan fermentasi tidak hanya aman dikonsumsi tetapi juga berkhasiat bagi kesehatan. Hal ini disebabkan selama proses, beberapa senyawa anti gizi maupun yang bersifat racun bisa diturunkan atau dikonversi menjadi senyawa yang bermanfaat, sehingga makanan fermentasi menjadi aman dikonsumsi bahkan mempunyai senyawa spesifik yang berfungsi sebagai senyawa fungsional dan mengatur proses metabolisme senyawa lain sehingga proses pencernaan menjadi lebih baik. Yang termasuk makanan fermentasi diantaranya ; tempe, tapai, dan sayur asin (asinan sayur), bekasam dan sejenisnya (produk fermentasi bakteri asam laktat). Tempe mampu mengatur gula darah dengan asam fitatnya, tapai bisa menyegarkan tubuh melalui vitamin B1 nya, dan sayur asin (asinan), bekasam merupakan produk fermentasi bakteri asam laktat yang berperan sebagai anti karsinogenik.
\end{abstract}

Kata Kunci: Manfaat, keamanan, makanan fermentasi

\begin{abstract}
According to some researches, fermented traditional food is safe for consumption dan beneficial for our health. This is coused by the fact that during the fermentation process some poisonous anti-nutrition compounds can be derived or converted into beneficial compounds to such an extend that the fermented food is safe for consumption or even has specific compounds functioning as functional compounds that regulates the metabolism of other compounds as to make the digestive process a better process. Included in fermented food are soybean curd, fermented cassava, salted vegetable, bekasam and the like (the product of the fermentation of lactic acid bacteria), etc. Soybean curd can regulate blood lucose with its fitat acid, soybean curd can make the body with its vitamin B1, and salted vegetable is a product of lactic acid bacteria fermentation that plays a role as anti-carcino genesis.
\end{abstract}

Key words : Anvantage, safety, fermente food.

\section{PENDAHULUAN}

Dulu, suatu bahan makanan dianggap memenuhi syarat apabila memenuhi tiga kreteria utama, yakni aman untuk dikonsumsi (safety), bergizi (nutritious), dan 
enak, lezat atau estetis (palatable). Sekarang suatu bahan makanan dianggap belum afdol apabila tidak mengandung syarat yang keempat, yakni memiliki sifat medis (medical property). Aman berarti tidak mengandung senyawa anti gizi dan senyawa yang membahayakan bagi kesehatan atau beracun. Bergizi berarti bahwa makanan yang dimakan dapat mensuplai zat-zat yang dibutuhkan oleh tubuh, seperti karbohidrt, lipida, protein, vitamin, dan mineral. Falatable, sangat penting bagi suatu makanan hubungannya dengan daya terima konsumen, artinya, suatu bahan makanan bisa dipertimbangkan menjadi makanan kalau disenangi secara organoleptik (flavour dan penampakkan) oleh konsumen dan secara estetis layak untuk dijadikan makanan. Suatu makanan akan memberikan nilai tambah apabila bermanfaat bagi kesehatan tubuh, kerena mengandung senyawa fungsional yang memiliki nilai medis (medical value), seperti antikarsinogenik, antioksidan, dan antimikrobia. Beberapa makanan diyakini memenuhi kreteria seperti itu,diantaranya adalah makanan fermentasi.

Makanan fermentasi, adalah makanan yang diproses melalui bantuan mikroorganisme atau komponen biologis lain seperti enzim, sehingga memberikan produk sedemikian rupa yang menguntungkan bagi manusia dari sudut pandang kesehatan (Pambayun, 2005). Makanan fermentasi termasuk makanan tradisional, karena prosesnya merupakan warisan turun temurun hasil temuan nenek moyang. Di Indonesia, ada beberapa makanan fermentasi yang bertarap nasional maupun menuju sosialisasi ke taraf nasional bahkan internasional, seperti tempe, tapai, teh hijau, sayur asin, bekasam dan lain-lain.

Banyak orang menggemari makanan fermentasi, tetapi hanya sedikit yang menyadari bahwa makanan fermentasi memiliki keunggulan terutama dari segi manfaat (khasiat) dan keamanan bagi kesehatan. Untuk itu, melalui tulisan ini disajikan manfaat dan keamanan beberapa makanan fermentasi, berdasarkan tinjauan dari sudut ilmu pangan. Diharapkan tulisan ini dapat memberikan kontribusi yang berarti bagi masyarakat Indonesia, serta memiliki kebanggaan terhadap makanan hasil temuan nenek moyang sendiri yang berupa makanan fermentasi. 


\section{PEMBAHASAN}

\subsection{Tempe Menurunkan Gula Darah dan Mencegah Kangker}

Tempe diproduksi dari bahan kedelai melalui proses fermentasi dengan menggunakan jamur Rhizopus sp. Karena fermentasi, protein terhidrolisis menjadi senyawa penyusunnya seperti asam amino da peptide, sehingga tempe lebih bergizi. Tempe juga sebagai sumber vitamin B12 yang dihasilkan oleh bakteri Klebsiella. Dalam setiap $100 \mathrm{~g}$ tempe terdapat $8,8 \mu \mathrm{g}$ B12. Selama fermentasi, bau langu pada kedelai menjadi hilang dan rasa tempe menjadi lebih enak, dalam istilah tertentu, tempe disebut memiliki cita rasa seperti daging (meat-like flavor). Diketahui, dalam kedelai terdapat asam fitat sekitar 1,1-1,5\%. Asam fitat, bersifat anti gizi dan menghalang-halangi penyerapan makanan khususnya karbohidrat, karena bersifat anti-amilase. Amilase adalah enzim yang berperan dalam hidrolisis pati menjadi gula sederhana (glukosa) sehingga mudah diserap oleh usus halus. Apabila aktivitas amilase dihambat (oleh asam fitat), maka pencernaan karbohidrat kurang sempurna, dan banyak yang lolos masuk dalam usus besar sebagai komponen oligosakarida. Oligosakarida merupakan umpan yang baik bagi mikroflora usus besar, dan terjadi perombakan hingga menghasilkan gas berlebihan (flatulensi). Pada kondisi yang demikian, meski karbohidrat (sumber energi) yang dikonsumsi cukup, namun tidak mencukupi kebutuhan dalam tubuh

Pada tempe, melalui proses fermentasi, asam fitat bisa diturunkan hingga 30\%. Sehingga, dalam tempe yang telah semangit (jamur tempe atau Rhizopus sp. masih berupa miselium putih belum banyak membentuk spora), kadar asam fitat tidak lebih dari 1\%. Pada kadar sebesar itu, asam fitat tidak lagi berfungsi sebagai penghambat tetapi dapat bermanfaat mengatur proses metabolisme karbohidrat sehingga tidak terjadi lonjakan gula darah (hiperglisemia). Hal ini sangat bermanfaat bagi tubuh, khususnya bagi penderita diabetes militus (Pambayun, 2005). Adanya mekanisme pengaturan itu, begitu karbohidrat masuk dalam saluran pencernaan, seolah-olah diatur penyerapannya sedikit-demi sedikit oleh asam fitat tempe, sehingga jumlah glokosa darah dapat dikendalikan.

Manfaat tempe lainnya adalah karena di dalamnya terdapat senyawa fungsional isoflavon, yang diyakini sebagai senyawa antikarsinogenik khususnya 
bagi para wanita. Asupan isoflavon dari kedelai (dalam kedelai mengandung isoflavon 0,2-1,5 mg/g) menurunkan resiko kangker payudara dan prostat (Shaw Watanabe, 2012). Lebih lanjut, Watanabe menyatakan, senyawa isoflavon terbukti dapat menurunkan kadar lemak darah atau kadar kolesterol total LDL (Low Density Lipoprotein). Jadi, tempe selain aman, bergizi, dan enak, juga mengandung senyawa fungsional isoflavon yang bersifat sebagai antikarsinogenik.

\subsection{Tapai Untuk Kesegaran Tubuh}

Tapai adalah makanan fermentasi dari ubi kayu atau beras ketan oleh mikroorganisme golongan yeast, diantaranya Candida sp., Endomycocsis sp., Hansenula sp., dan Saccharomyces sp. Mikroorganisme tersebut ada tergolong amilotelik (merubah amilum menjadi glukosa), sakarolitik (merubah glukosa menjadi alkohol), dan alkoholitik (merubah alkohol menjadi asam asetat). Dari hasil fermentasi, tapai memiliki berbagai rasa, manis, alkoholis, dan bisa berasa sedikit asam yang dalam proporsi tertentu sehingga memberikan rasa enak. Sifat tekstur, rasa, dan aroma akan lebih baik apabila sebelum diolah, bahan tapai direndam dalam air kapur.

Selama fermentasi, kandungan protein meningkat dari $1-2 \%$ menjadi $4 \%$, demikian juga kandungan tiamin dan terosinnya meningkat secara berturut-turut dari $0,04 \mathrm{mg} / 100 \mathrm{~g}$ menjadi $0,1 \mathrm{dan} 0,12 / \mathrm{g}$. Jadi tapai lebih bergizi dibandingkan dengan bahan dasarnya. Bahkan, ada beberapa hipotesa bahwa selama fermentasi, kandungan HCN ubi kayu dapat dihilangkan atau diturunkan, meski balum jelas mekanismenya (Steinkraus, 2010).

Dari sudut pandang manfaat (khasiatnya), kelebihan utama tapai adalah memiliki vitamin B1 sekitar 300\% dibanding bahan dasarnya, ubi kayu maupun beras ketan. Diketahui, tapai rendah alkohol, dengan pemberian ragi kurang dari 1\% dengan masa inkubasi 3 hari (Hidayat, et, al, 2009) atau tapai dengan kondisi fermentasi aerobic dapat bermanfaat bagi tubuh.

Mengkonsumsi tapai berarti mengkonsumsi vitamin B1 dengan berkecukupan yang berperan dalam metabolisme energi tubuh. Tubuh manusia memerlukan 0,5 mg vitamin B1 untuk setiap kebutuhan kalori sebesar 1000 kalori, 
atau sekitar 0,7 untuk balita, 1,0 untuk pria, dan 0,9 untuk wanita per hari. Meskipun kebutuhan tubuh akan vitamin B1 relatif kecil, namun untuk memenuhi kebutuhan itu tidak mudah (Pambayun, 2005).

Salah satu fungsi vitamin B1 dalam tubuh adalah sebagai koenzim tiamin pyrophosphate (TPP) yang mengkatalis karbohidrat, lemak, atau protein untuk menghasilkan energi. Kegagalan metabolisme energi dapat mempengaruhi neuron dan fungsinya pada bagian tertentu dari system syaraf pusat. Cara yang mudah untuk memenuhi kekurangan vitamin B1 adalah membiasakan dengan mengkonsumsi tapai setiap hari. Dengan mengkonsumsi sedikit tapai sebagai makanan ringan, kekurangan vitamin B1 dapat tercukupi, sehingga tubuh menjadi segar.

Jadi, tapai selain aman (bebas HCN dari ubi kayu), bergizi (senyawasenyawa karbohidrat sederhana, protein dari yeast dan vitamin B1), enak, juga memiliki nilai medis yakni menyegarkan tubuh jika dikonsumsi dalam jumlah secukupnya. Oleh karena itu, makan tapai sebagai makanan ringan setiap hari merupakan kebiasaan baik, untuk menjaga kesegaran tubuh.

\subsection{Produk Fermentasi Bakteri Asam Laktat Sebagai Anti Karsinogenik}

Indonesia kaya akan makanan fermentasi dengan bakteri asam laktat, diantaranya adalah sayur asin, bekasam, tempoyak. Bekasam adalah makanan yang terbuat dari ikan dan nasi. Tempoyak dibuat dari buah durian. Semuanya dibuat melalui proses fermentasi dalam keadaan salinitas tinggi dan kondisi anaerob. Pada keadaan dan kondisi itu, mikroorganisme yang tumbuh dominan adalah bakteri asam laktat (Leuconostoc, Streptococcus, Pediococcus, dan Lactobacillus).

Selama proses fermentasi, makromolekul seperti protein dan karbohidrat dihidrolisis sehingga menjadi asam-asam amino dan gula sederhana, yang meningkatkan nilai gizi serta terbentuk senyawa penyumbang citarasa (flavor). Setelah proses fermentasi, nilai gizi, flavor, dan tekstur menjadi lebih baik.

Bakteri asam laktat juga menghasilkan senyawa bakteriosin, yang dapat merepresi mikroba patogen seperti jamur, sehingga kemungkinan tumbuh mikrobia yang berbahaya dapat dihindari. Hal ini memberikan efek aman bagi makanan fermentasi bekasam dan yang lainnya. 
Lebih jauh diketahui bahwa selama proses fermentasi, bakteri asam laktat menghasilkan asam-asam organik rantai pendek. Asam-asam organik seperti itu memberikan kontribusi sehat bagi yang mengkonsumsi karena bersifat antikarsinogenik.

\section{PENUTUP}

Berdasarkan uraian tersebut di atas dapat disimpulkan sebagai berikut:

1. Beberapa makanan fermentasi memiliki keunggulan terutama dari segi keamanan dan manfaatnya (khasiatnya) bagi kesehatan.

2. Tempe, selain aman, enak karena memiliki rasa seperti daging (meat-like flavor), juga bergizi terutama nilai gizi protein dan vitamin B12 nya, dan mengandung senyawa fungsional isoflavon yang bersifat sebagai antikarsinogenik.

3. Tapai selain aman (bebas HCN dari ubikayu), bergizi (senyawa-senyawa karbohidrat sederhana dan protein dari yeast dan vitamin B1), enak, juga memiliki nilai medis yakni menyegarkan tubuh jika dikonsumsi dalam jumlah secukupnya. Oleh sebab itu, makan tapai sebagai makanan ringan setiap hari merupakan kebiasaan baik, untuk menjaga kesegaran tubuh.

4. Diketahui bahwa selama proses fermentasi pada sayur asin, bekasam, dan sejenisnya, bakteri asam laktat menghasilkan asam-asam organik rantai pendek. Asam-asam organik seperti itu memberikan kontribusi sehat bagi yang mengkonsumsi karena bersifat antikarsinogenik.

\section{DAFTAR PUSTAKA}

Hidayat, A. 2009. Tapai Makanan Pengobat Rasa Malas. Yogyakarta: Kanisius.

Pambayun, R. 2005. Makanan Fermentasi Tradisional Indonesia, Nilai gizi dan Kajian Manfaatnya. Prosiding Widya Karya Nasional Khasiat Makanan Tradisional, Jakarta.

Watanabe Shaw, 2012. Kedelai Stabilkan Kadar Gula Darah. Bali fost, Rabu Wage, 8 Agustus 2012.

Steinkraus, K.H. 2010. Inustrialization of Indigenous Fermented Food. Marcel Dekker, Inc New York and Basel. 